\title{
BEBAN GANDA PENGELOLAAN AIR TANAH DI KABUPATEN/KOTA PASCA PEMBATALAN UU NO 7/2004 TENTANG SUMBER DAYA AIR: ILUSTRASI DARI KOTA BANDUNG
}

\author{
Dasapta Erwin Irawan ${ }^{1^{*}}$, Achmad Darul $^{2}$, Hendy Sumadi ${ }^{3}$, Arno \\ Adi Kuntoro ${ }^{1}$, Teti Armiati Argo ${ }^{1}$, Yunie Nurhayati ${ }^{1}$ \\ ${ }^{1}$ Fakultas IImu dan Teknologi Kebumian, Institut Teknologi \\ Bandung \\ ${ }^{2}$ Sekolah Arsitektur, Perencanaan, dan Pengembangan \\ Kebijakan, Institut Teknologi Bandung \\ ${ }^{3}$ Fakultas Teknik dan Desain, Institut Teknologi dan Sains \\ Bandung
}

e-mail: dasaptaerwin@gmail.com

\begin{abstract}
Abstrak
Indonesia sedang memiliki beban ganda dalam menyelesaikan masalah pengelolaan sumber daya air, khususnya air tanah. Selain karena pembatalan UU No. 7/2004, juga karena pengalihan kewenangan pengelolaan dari pemerintah kabupaten/kota ke pemerintah provinsi sebagai dampak dari UU No. 23/2014. Karena proses komunikasi antara provinsi dan kabupaten/kota tidak mulus, karena berbagai alasan, akibatnya regulasi tidak kunjung dibuat. Pada akhirnya kondisi air tanah akan semakin buruk.Makalah ini mencoba mendudukkan kembali berbagai aspek pengelolaan air tanah yang telah dirumuskan sebelumnya dan masih relevan untuk dijalankan saat ini. Kemudian dipilihlah aspek konservasi dan pemberdayaan sebagai aspek yang dapat dikerjasamakan antara pemerintah provinsi dan pemerintah kabupaten/kota, karena: aspek ini lebih berkaitan dengan aspek monitoring atau pemantauan. Yang mana, pemantauan akan lebih baik dilakukan oleh pemerintah kabupaten/kota karena skala pemetaan yang lebih rinci, dibanding bila dilakukan pada skala provinsi. Selain itu instrumentasi pemantauan yang dimiliki oleh organ tingkat kabupaten/kota lebih lengkap dibanding pemerintah provinsi.

Kata kunci: Regulasi, Pengelolaan Air Tanah, Cekungan Air Tanah
\end{abstract}

\begin{abstract}
Abtract
Indonesia currently has a double burden in solving the problem of water resources, particularly groundwater. In addition to the cancellation of Law No. $7 / 2004$, as well as the transfer of management authority of district/city government to the provincial government as a result of Law No. 23/2014. Due to the communication process between the provincial and district /city is not good, for various reasons, not being made as a result of regulation. Ultimately groundwater conditions will be getting worse. This paper tries to reinstate the various aspects of groundwater management has been formulated previously and are still relevant to the current run. Then chosen aspects of conservation and empowerment as an aspect to cooperation between the provincial and district /city government, because: this aspect is more related to aspects of monitoring. Which, monitoring would be better done by the district /city for more detailed mapping scale. Besides monitoring instrumentation owned by organs of district/municipal level is more complete than the provincial government.
\end{abstract}

Keywords: Regulation, Groundwater Management, Groundwater Basin 


\section{PENDAHULUAN}

Dengan pembatalan UU No. 7/2004 tentang Sumber Daya Air oleh Mahkamah Konstitusi, maka seluruh regulasi turunannya di tingkat pusat, provinsi dan kabupaten/kota secara otomatis akan menjadi batal demi hukum. Akibatnya terjadi kekosongan regulasi dalam pengelolaan sumber daya air di Indonesia. Kekosongan ini tidak mendapatkan respon yang tanggap dari pihak yang berwenang. Berkaitan dengan hal tersebut, saat ini sumber daya air telah mendapat kendala ganda dalam periode tiga tahun terakhir. Makalah berikut ini bertujuan untuk mengurai situasi tersebut khusus dalam pengelolaan air tanah di Kota Bandung. $\mathrm{Di}$ bawah ini akan dijelaskan tiga pertimbangan yang menjadikan masalah tersebut krusial untuk segera ditangani. Pertama, pembatalan UU No. 7/2004 tentang sumber daya air. Air merupakan kebutuhan dan salah satu hak asasi manusia sehingga pengadaan kebutuhan air kepada masyarakat merupakan kewajiban pemerintah. Salah satu sumber air bersih yang digunakan oleh masyarakat adalah air tanah. Karena kebutuhan akan air terus meningkat, maka pengguna air, baik sektor industri maupun rumah tangga berlomba menambah debit pemompaannya, yang pada akhirnya akan saling merugikan. Sebagian masyarakat akan memiliki akses air secara tidak terbatas, sedangkan sebagian lainnya terabaikan. Amanat Pasal 33 ayat (3) UUD 1945 menjadi terabaikan. Oleh karena itu, air harus dikelola dengan struktur regulasi yang baik (PAAl, 2016). Di sisi lain, pada bulan Februari 2015, Mahkamah Konstitusi melalui keputusannya No. 85/PUU-XI/2013 tentang Pembatalan Undang-undang No. 7/2004 Tentang Sumber Daya Air, secara langsung telah menghapus berbagai regulasi tentang sumber daya di Indonesia. Dengan kata lain, Indonesia saat ini sedang tidak memiliki regulasi tentang sumber daya air.

Kedua, air tanah yang terlupakan. Di sisi lain, air tanah adalah komponen air yang mendapat perhatian paling rendah, dengan dukungan regulasi yang minimum. Berbeda dengan air permukaan yang sejak tahun 1970 an telah memiliki set regulasi yang terstruktur, sehingga begitu UU No. 7 tahun 2004 dihapus, maka aturan lama yang telah lengkap relatif dapat menggantikannya secara langsung. Bahkan bila dilihat pada UU No. 11/1974 tentang Pengairan, air tanah hanya mendapatkan porsi satu pasal, yakni pada pasal 5 ayat 2 , yang menerangkan bahwa "Pengurusan administratip atas sumber air bawah tanah dan mata air panas sebagai sumber mineral dan tenaga adalah diluar wewenang dan tanggung-jawab Menteri yang disebut dalam ayat (1) pasal ini".

Ketiga, masalah ganda regulasi. Pembatalan UU No. 7/2004 bukanlah satu-satunya masalah pengelolaan air di Indonesia. Perubahan lainnya yang sangat mempengaruhi kewenangan pengelolaan sumber daya kebumian adalah UU 23/2014 tentang Pemerintah Daerah yang merevisi UU 32/2004 tentang hal yang sama.

\section{METODE}

Metode yang digunakan adalah telaah regulasi berdasarkan kondisi eksisting. Data regulasi kami dapatkan dari internet, yaitu website Kementerian Dalam Negeri (http://www.kemendagri.go.id/produkhukum), Kementerian Energi dan Sumber Daya Mineral (www.esdm.go.id/), Pemerintah Provinsi Jawa Barat (http://jdih.jabarprov.go.id), dan Pemerintah Kota Bandung (http://jdih.net). Selain itu dilakukan dialog dengan pemangku kepentingan: Badan Pengelola Lingkungan Hidup Kota Bandung, DPRD Kota Bandung, para pelaku usaha (mayoritas usaha perhotelan dan tekstil), dinas-dinas terkait antara lain Dinas Tata Ruang dan Pemukiman, Dinas Perindustrian, Perusahaan Daerah Air Minum Kota Bandung, Dinas Energi dan Sumber Daya Mineral Provinsi Jawa Barat. Dari data tersebut, dibuat alur kronologis perubahan regulasi. Kemudian, ditarik benang merah antara kondisi air tanah yang sudah semakin rusak dengan kekosongan regulasi, sampai kepada usulan lingkup Raperda tentang Konservasi Air Tanah. 
HASIL DAN PEMBAHASAN

Prinsip Umum Pengelolaan Air Tanah

Prinsip umum pengelolaan air tanah sebagai bagian dari sumber daya air secara keseluruhan akan mengikuti konsep pengelolaan terintegrasi dan berkelanjutan. Siklus hidrogeologi atau siklus air tanah erat hubungannya dengan siklus air meteorik. Keduanya siklus ini merupakan bagian dari siklus hidrologi di permukaan bumi (Gambar 1). Pemahaman berkenaan dengan sistem hidrologi di suatu kawasan yang akan dikembangkan menjadi landasan utama di dalam menentukan pilihan yang optimal untuk merencanakan penanganan masalah sumberdaya air. Oleh karena itu, karakteristik sistem hidrologi global dan karakter lokal sangat penting untuk dipelajari.

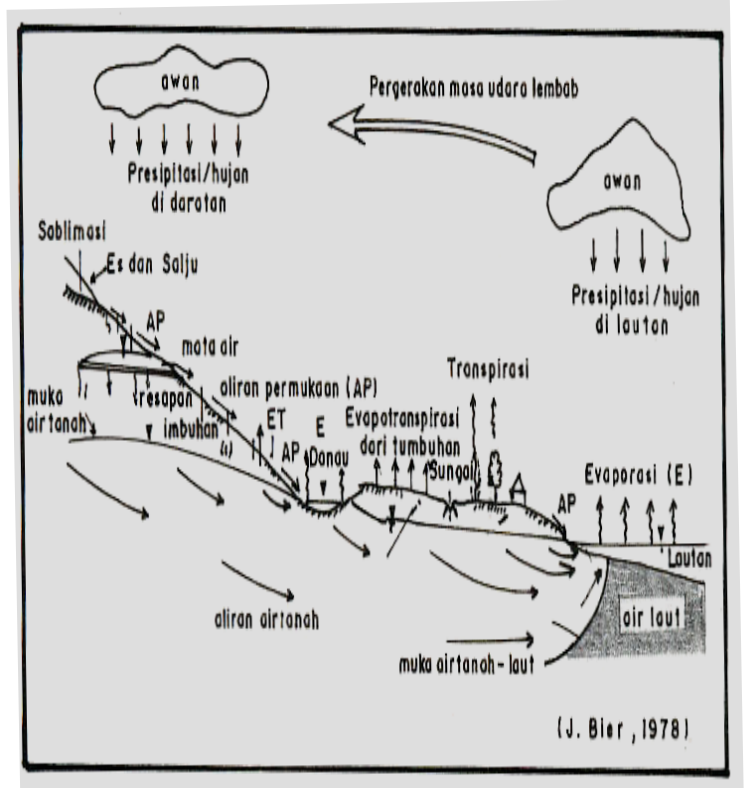

Gambar 1 Siklus Hidrologi (dimodifikasi dari Bear, 1978)

Secara lebih rinci, pemahaman suatu sistem hidrologi di alam meliputi tiga bagian (Gambar 2) (Castany, 1982): Hidrometeorologi, khususnya perilaku sumber air hujan; Cekungan hidrologi atau Daerah Aliran Sungai (DAS); dan cekungan hidrogeologi untuk air tanah. Dari uraian ini, bahwa berbagai jenis air tersebut perlu dikelola bersama. Masingmasing saling mempengaruhi, dalam hal kuantitas maupun kualitas.

Sejalan dengan peniNgkatan pemompaan air tanah, konservasi air tanah menjadi penting dalam sejak 30 tahun terakhir. Sampai saat ini konservasi air tanah di Indonesia masih menggunakan pola pikir pengelolaan sumur produksi belum memperhatikan sistem hidrogeologi secara lengkap, yang biasanya dinyatakan dalam satuan cekungan airtanah (CAT). Karena hanya berpatokan kepada pengambilan air di sumur produksi, maka beberapa kelemahan dalam pendekatan ini adalah (Puradimaja 2006; Mandel dan Shiftan 1981, Shibasaki 1995, dan Lerner et al. 1997): (1) tidak diketahuinya potensi riil setiap akifer yang dieksploitasi, (2) tidak ada optimasi eksploitasi air tanah pada setiap akifer akibatnya perubahan lingkungan bawah permukaan tidak dapat dikendalikan, dan (3) tidak dapat dilakukannya pengendalian kualitas air tanah pada sumur produksi.

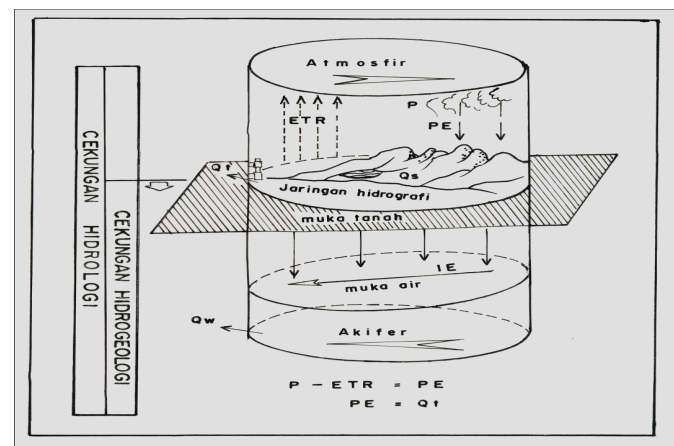

Gambar 2 Tiga sistem hidrologi di alam (Castany, 1982) 


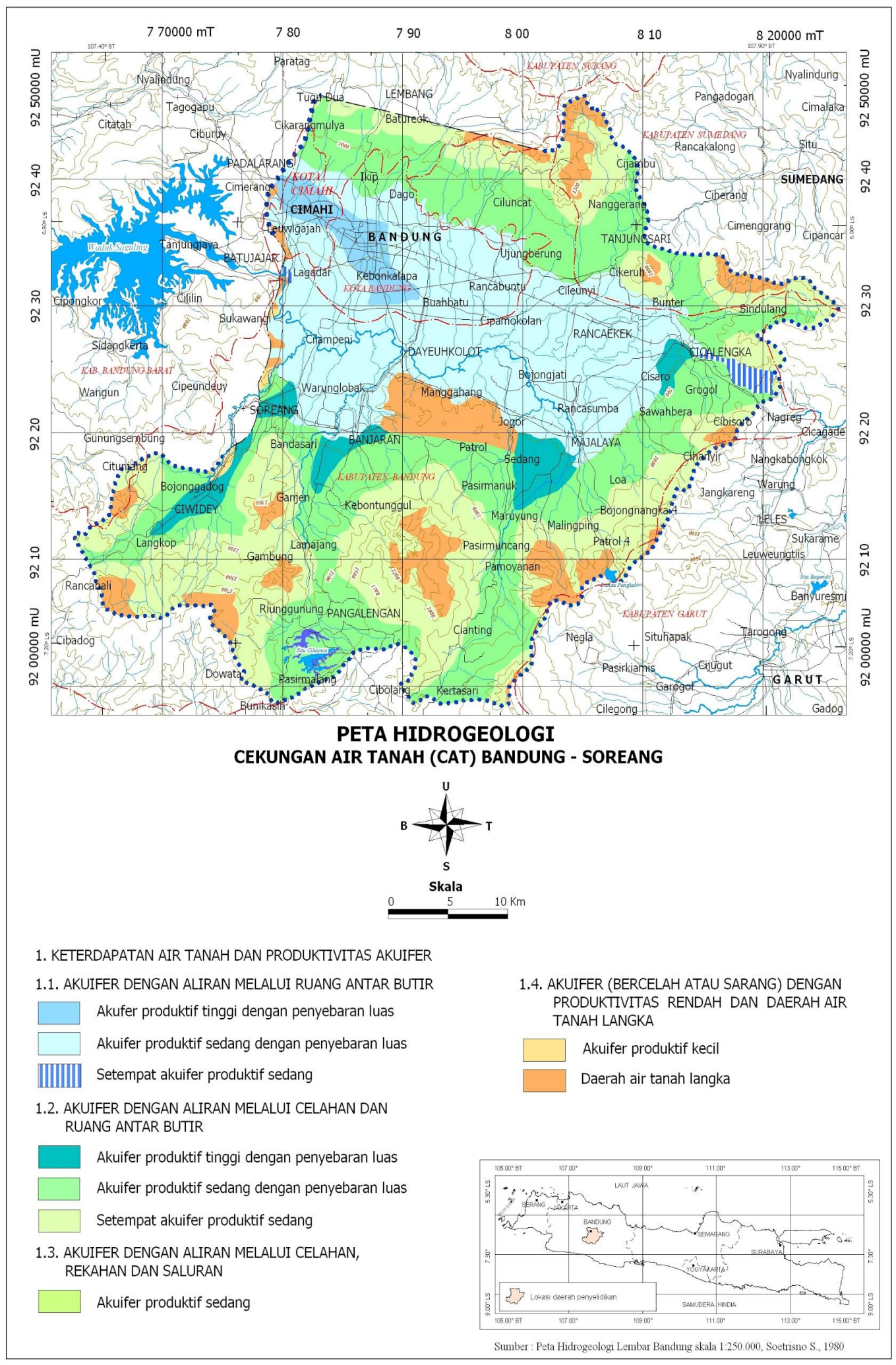

Gambar 3 Batas wilayah Cekungan Air Tanah Bandung - Soreang (Deltares, 2012) 


\section{EVALUASI PERATURAN TERKAIT}

\section{DAN ANALISIS PERUNDANGAN}

\section{Era pra UU 7/2004 tentang Sumber daya air}

Djaendi (2003) menyatakan bahwa pada jaman penjajahan Belanda pengaturan pengelolaan air pada umumnya dan air tanah secara khusus, sudah dilakukan secara tertulis pada tahun 1871 dan 1936. Inti dan peraturan tersebut membatasi pengambilan air tanah pada kedalaman lebih dari 15 meter (perlu izin khusus). Pada era kemerdekaan pengelolaan air tanah diatur dalam UUD 45 Pasal 33, ayat (3); UU No. 11 tahun 1974 tentang Pengairan; PP No. 22 tahun 1982 tentang Tata Pengaturan Air, KepMen PE. NO.03.P/M/Pertamben/1983; KepMen PE. No. 08P/03/M.PE/1991; Kepmen PE. NO.02P/101/M.PE/1994.

Pengelolaan air tanah sejak tahun 1983 telah dilakukan oleh Gubemur sebagai tugas perbantuan, dan sejak tahun 1995 melalui Keputusan Menteri Pertambangan dan Energi No. 1945K/102/M.PE/1995 sebagian pengelolaan air tanah dilakukan oleh pemda TK.II Otonom dengan pembinaan dan Departemen Pertambangan dan Energi.

Pada era reformasi, pemerintah telah menerbitkan Kepmen ESDM No. $1451 \mathrm{~K} / 10 / \mathrm{MEM} / 2000$ tentang Pedoman Teknik Penyelenggaraan Pemerintahan dibidang Air Bawah Tanah dan Kepmen ESDM No. 716K/40/MEM/2003 tentang Batas Horisontal Cekungan Air Tanah di Pulau Jawa dan Pulau Madura, sebagai acuan dan pegangan di dalam pengelolaan air tanah di daerah. Pengelolaan sumberdaya air tanah diharapkan akan dilakukan lebih seksama, dalam arti pengelolaan sumberdaya airtanah akan lebih diatur di daerah dengan mempertimbangkan kondisi lingkungan, sosial, ekonomi, politik dengan menerapkan teknologi yang tepat.

Dari sisi sistem dan struktur pemerintahan, dengan berlakunya UU No. 22 Tahun 1999, UU No. 25 Tahun 1999 dan PP No. 25 Tahun 2000 dimana terjadi perubahan sistem pemerintahan dari sentralistik ke sistem desentralistik dengan memberikan otonomi kewenangan menjalankan pemerintahan lebih luas ke daerah. Pengelolaan airtanah juga lebih banyak dilakukan dan menjadi wewenang daerah, sedangkan pusat bertindak sebagai fasilitator dan koordinator sebatas membuat kebijakan, standart, norma, kriteria, prosedur, pedoman, dan pengaturan survei dasar airtanah skala lehih kecil atau sarna dengan $1: 250.000$ serta penyusunan peta tematis.

Kewenangan Provinsi sesuai UU No. 22 Tahun 1999 dan PP No. 25 Tahun 2000, antara lain penyediaan dukungan pengembangan dan pemanfaatan airtanah, pelatihan dan penelitian di bidang air tanah, pelayanan pengelolaan air tanah pada cekungan lintas Kabupaten/Kota melalui kerjasama antar daerah, sehingga tidak menimbulkan kerugian di semua pihak. Kewenangan Kabupaten/Kota berdasarkan Keputusan Menteri Dalam Negeri No.130-67 tahun 2002, tentang Kewenangan Kabupaten/Kota di bidang Energi dan Sumber Daya Mineral, pada bagian Pengelolaan Air Bawah Tanah adalah:

1) Melaksanakan pengelolaan air bawah tanah sesuai kebijakan, pedoman, prosedur, standar, norma, persyaratan, dan kriteria di bidang air bawah tanah.

2) Melaksanakan inventarisasi dan perencanaan pendayagunaan airtanah dalam rangka pengelolaan, pemanfaatan, dan perlindungan airtanah dan atau mala air.

3) Menyiapkan kelembagaan, sumberdaya manusia, pengusahaan dan pembiayaan pendayagunaan dan pelestarian sumberdaya airtanah.

4) Melaksanakan pemantauan, pengendalian, pengawasan pengelolaan dan konservasi air tanah.

5) Melaksanakan pengaturan peruntukan pemanfaatan airtanah dan mata air.

6) Memberikan izin penelitian, eksplorasi, izin pemboran, izin penurapan mata air dan izin pengambilan air tanah dan mata air. 
7) Memberikan Surat Izin Juru Bor (SIJB) air tanah.

8) Memberikan Surat Izin Usaha Perusahaan Airtanah.

9) Penetapan dan mengatur sistem jaringan sumur pantau dalam satu cekungan airtanah.

10) Pengumpulan dan pengelolaan data dan informasi airtanah dan atau mata air.

11) Mendorong peran masyarakat dalam kegiatan perencanaan, pendayagunaan, pengendalian dan pengawasan dalam rangka konservasi airtanah.

12) Guna mengatur pelaksanaan kewenangan tersebut tiap kabupaten/kota perlu membuat peraturan daerah.

Dalam pengelolaan air tanah Pemerintah melalui Departemen Energi dan Sumber Daya Mineral, sudah mengeluarkan Keputusan Menteri No. $1451 \mathrm{~K} / 10 / \mathrm{MEM} / 2000$ tentang Pedoman Teknis Penyelenggaraan Tugas Pemerintahan di Bidang Air Bawah Tanah, yang dilengkapi dengan 11 pedoman ikutannya yang sekaligus mencabut Keputusan menteri sebelumnya mengenai pengelolaan airtanah yang ada di tingkat pemerintah pusat. Keputusan Menteri Energi dan Sumber Daya Mineral No. 716 $\mathrm{K} / 40 / \mathrm{MEM} / 2003$ tentang Batas Horisontal Cekungan Air Tanah di $\mathrm{P}$. Jawa dan P. Madura, yang terdiri dari 80 cekungan air tanah. Selain itu Pemerintah telah menerbitkan enam standardisasi di bidang air tanah melalui Badan Standardisasi Nasional (BSN). Semua pedoman, standard, norma dsb. yang dibuat pusat merupakan dasar dalam pembuatan aturan pengelolaan air tanah di daerah.

Di dalam Keputusan Menteri No. 1451/10/MEM/2000 Tahun 2000 tentang Pedoman Teknis Penyelenggaraan Tugas Pemerintahan di Bidang Air Bawah Tanah, pengelolaan cekungan air tanah yang melintasi wilayah Provinsi atau Kabupaten/Kota ditetapkan oleh masing-masing Gubernur atau Bupati/Walikota berdasarkan kesepakatan Bupati/Walikota yang bersangkutan dengan dukungan koordinasi dan fasilitasi dari Gubernur.

\section{Era UU 7/2004 tentang Sumber Daya Air}

Undang-Undang No. 7/2004 Tentang Sumber Daya Air mengubah kondisi pengelolaan sumber daya air secara mendasar. Perubahan tersebut terkait dengan reformasi kebijakan pengelolaan sumberdaya air yang dimulai sejak Tahun 1993, namun secara efektif baru dilaksanakan Tahun 1999. Pada era ini terjadi perubahan paradigma yang mendasar, dari pendekatan penyediaan (supply approach) menjadi pendekatan permintaan (demand approach), sehingga kemudian pada berbagai daerah ditetapkan harga air yang bersumber dari Nilai Perolehan Air (NPA). UU ini sangat terkait dengan beberapa produk regulasi sebagai berikut:

1) Undang-Undang No. 32/2004 Tentang Pemerintahan Daerah. Ada kewenangan tentang pengelolaan air tanah pada:

o Pasal 14 yang menyatakan bahwa Urusan wajib yang menjadi kewenangan pemerintahan daerah untuk kabupaten/kota merupakan urusan yang berskala kabupaten/kota meliputi beberapa hal, yang berkaitan dengan pengelolaan air tanah adalah dua hal berikut ini:

- ayat d. penyediaan sarana dan prasarana umum (bahwa air merupakan salah satu sarana dan prasarana umum, untuk itu pemerintah kabupaten/kota berkewajiban menyediakan fasilitas ini, salah satunya bersumber dari air tanah).

- ayat j. pengendalian lingkungan hidup (bahwa air tanah merupakan salah satu komponen lingkungan hidup yang perlu dikendalikan pemanfaatannya).

- Pasal 17 yang menyatakan bahwa:

- ayat (1) Hubungan dalam bidang pemanfaatan sumber daya alam dan sumber daya 
lainnya antara Pemerintah dan pemerintahan daerah sebagaimana dimaksud dalam Pasal 2 ayat (4) dan ayat (5) meliputi (bahwa air tanah merupakan salah satu dari sumber daya alam):

a. kewenangan, tanggung jawab, pemanfaatan, pemeliharaan,

pengendalian dampak, budidaya, dan pelestarian (bahwa pengelolaan air tanah sebagai salah satu sumber daya alam adalah mencakup poin-poin di atas);

b. bagi hasil atas pemanfaatan sumber daya alam dan sumber daya lainnya; dan

c. penyerasian lingkungan dari tata ruang serta rehabilitasi lahan.

- ayat (2) Hubungan dalam bidang pemanfaatan sumber daya alam dan sumber daya lainnya antar pemerintahan daerah sebagaimana dimaksud dalam Pasa1 2 ayat

(4) dan ayat (5) meliputi:

a. pelaksanaan pemanfaatan sumber daya alam dan sumber daya lainnya yang menjadi kewenangan daerah (bahwa pemanfaatan air tanah sebagai salah satu sumber daya alam adalah menjadi kewenangan daerah, dalam hal ini adalah Kota Bandung);

b. kerja sama dan bagi hasil atas pemanfaatan sumber daya alam dan sumber daya lainnya antar pemerintahan daerah; dan

c. pengelolaan perizinan bersama dalam pemanfaatan sumber daya alam dan sumber daya lainnya (bahwa perizinan dalam pemanfaatan air tanah merupakan kewenangan daerah, dalam hal ini Kota Bandung).

- ayat (3) Hubungan dalam bidang pemanfaatan sumber daya alam dan sumber daya lainnya sebagaimana dimaksud pada ayat (1) dan ayat (2) diatur dalam peraturan perundangundangan.

2) UU No. 32/2009 Tentang Perlindungan dan Pengelolaan Lingkungan Hidup. Dalam UU ini AMDAL mendapat porsi yang cukup banyak dibandingkan instrumen lingkungan lainnya, dari 127 pasal yang ada, 23 pasal diantaranya mengatur tentang AMDAL. AMDAL dalam hal ini diposisikan sebagai salah satu instrumen pencegahan pencemaran dan/atau kerusakan lingkungan hidup. Selain itu pasal tentang sanksi juga dinilai terkait dengan pengelolaan sumber daya air, yakni:

o Sanksi terhadap orang yang melakukan usaha/kegiatan tanpa memiliki izin lingkungan;

- Sanksi terhadap pejabat yang memberikan izin lingkungan yang tanpa dilengkapi dengan dokumen AMDAL atau UKL-UPL.

3) PP No. 38/2007 tentang Pembagian Urusan Pemerintahan antara Pemerintah Pusat, Pemerintah Daerah Provinsi, dan Pemerintah Daerah Kabupaten/Kota:

o Pasal 7

- ayat (1) Urusan wajib sebagaimana dimaksud dalam Pasal 6 ayat (2) adalah urusan pemerintahan yang wajib diselenggarakan oleh pemerintahan daerah provinsi dan pemerintahan daerah kabupaten/kota, berkaitan dengan pelayanan dasar.

- ayat (2) Urusan wajib sebagaimana dimaksud pada ayat (1) salah satunya pada huruf "c" adalah lingkungan hidup (air tanah dalam hal ini termasuk ke dalam komponen lingkungan hidup, sehingga masuk ke dalam kewenangan pengelolaan oleh pemerintahan daerah);

- ayat (3) Urusan pilihan sebagaimana dimaksud dalam 
Pasal 6 ayat (2) adalah urusan pemerintahan yang secara nyata ada dan berpotensi untuk meningkatkan kesejahteraan masyarakat sesuai dengan kondisi, kekhasan, dan potensi unggulan daerah yang bersangkutan.

- ayat (4) Urusan pilihan sebagaimana dimaksud pada ayat (3) salah satunya adalah pada huruf "d" energi dan sumber daya mineral (air tanah merupakan salah satu bentuk energi, sehingga pengelolaannya menjadi kewenangan pemerintah daerah);

4) PP No. 43/2008 tentang Air Tanah. Mengatur tentang Kebijakan Teknis Pengelolaan Air Tanah yang terpadu sebagai bagian dari Kebijakan Sumber Daya Air. Kebijakan teknis tersebut didasarkan pada Cekungan Air Tanah yang ditetapkan dengan Keputusan Presiden. Kebijakan Teknis ditujukan sebagai arahan dalam konservasi air tanah, pendayagunaan air tanah, pengendalian daya rusak air tanah, sistem informasi air tanah dengan memperhatikan kondisi air tanah setempat. Kebijakan teknis tersebut dituangkan dalam Strategi Pengelolaan Air Tanah sebagai bagian dari Pola Pengelolaan Sumber Daya Air. Strategi Pengelolaan kemudian dijabarkan dalam Rencana Pengelolaan Air Tanah sebagai bagian dari Rencana Pengelolaan Sumber Daya Air, baik air tanah, air permukaan, air hujan dan air laut.

5) Kepmen ESDM 1451K/10/MEM/2000 Tentang Pedoman Teknis Penyelenggaraan Tugas Pemerintahan di Bidang Pengelolaan Air Bawah Tanah Menteri Energi Dan Sumberdaya Mineral. Pada Pasal 2 dinyatakan bahwa pengelolaan air bawah tanah didasarkan atas asas-asas yang masih sangat relevan dengan kondisi terkini: a. fungsi sosial dan nilai ekonomi;

b. kemanfaatan umum;

c. keterpaduan dan keserasian;

d. keseimbangan;

e. kelestarian;

f. keadilan;

g. kemandirian;

h. transparansi dan akuntabilitas publik.

Semangat mengelola air tanah yang terintegrasi juga diadopsi dari Perda Provinsi Jawa Barat No. 5/2008 tentang Pengelolaan Air Tanah. Pemerintah Provinsi Jawa Barat menuangkan kebijakan mengenai air tanah dengan konsep "One Groundwater Basin, One Planning, One Integrated Management".

6) Perda Kota Bandung No. 08/2007 tentang Urusan Pemerintahan Daerah Kota Bandung pada Pasal 2 yang menyatakan bahwa urusan pemerintah daerah (Kota Bandung) meliputi 31 (tiga puluh satu) bidang urusan. Dua hal yang termasuk di dalamnya adalah lingkungan hidup dan energi dan sumber daya mineral (dalam kajian ini, air tanah termasuk ke dalam salah satu komponen lingkungan hidup dan salah satu bentuk energi yang terbarukan, sehingga pengelolaannya merupakan kewenangan dari Kota Bandung).

Era Pasca Pembatalan UU 7/2004 tentang Sumber Daya Air dan ImplementasiUU 23/2014 tentang Pemerintahan Daerah

Undang-Undang ini memberikan warna baru ke dalam kondisi pemerintahan RI yang sebelumnya telah menganut konsep desentralisasi. Konsep tersebut pada banyak bagian dinilai banyak memberikan kewenangan yang tidak terbatas kepada kab/kota untuk mengelola sumber daya alam yang dimilikinya. Untuk itu pemerintah mencoba mendefinisikan kembali kewenangan tersebut dengan menerbitkan UU No. 23/2014.

Dalam UU tersebut, kewenangan pengelolaan air tanah sebagian besar ditarik kembali ke tingkat provinsi. Komponen perizinan dan pengawasan menjadi bagian kuat yang 
kewenangannya diambil alih oleh pemerintah provinsi (pemprov) sebagai kepanjangan tangan pemerintah pusat, karena kedua komponen ini dinilai sebagai komponen paling strategis dalam konservasi air tanah: (1) komponen perizinan sangat menentukan apakah pihak pengusul diberi izin untuk melakukan pemboran air tanah atau tidak berdasarkan kriteria yang ketat, dan (2) komponen pengawasan juga sangat menentukan karena dipandang sebagai instrumen indikator pemberian sanksi.

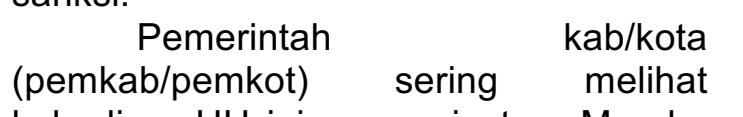

kehadiran UU ini secara instan. Merekaeng lebih banyak yang merasa kewenangannya dipindahkan seluruhnya ke pemprov. Di sisi lain, pemprov sendiri secara alamiah sangat memerlukan dukunan pemkab/pemkot untuk dapat melaksanakan amanat UU dengan baik. Basis data sistem hidrogeologi atau cekungan air tanah (CAT) akan lebih lengkap bila pemkab/pemkot turut ambil peran merinci data dengan skala pemetaan yang lebih detil. Hal yang senada juga disampaikan oleh Rachman (2015).

Dengan demikian dengan terbitnya UU No. 23/2014, kewenangan pemkab/pemkot memang banyak yang diambil alih provinsi, namun hal tersebut tidak serta merta membuat pemkab/pemkot tidak boleh melaksanakan kegiatan konservasi. Sesuai dengan tingkat kewenangannya, pemkab/pemkot tetap dapat melaksanakan kegiatan pemantauan, pembinaan, penyediaan basis data dan sistem informasi, dalam lingkup mendukung provinsi.

Dari uraian di atas dapatlah kita tarik kesimpulan sementara sebagai berikut. Pertama, bahwa UU No. $11 / 1974$ sebagai pengganti UU No. 7/2004 sebenarnya tidak mengatur air tanah. Kedua, bahwa regulasi-regulasi di bawahnya (UU No. 11/1974) sudah sangat tidak relevan dengan kondisi saat ini dengan jumlah pemompaan air tanah yang sangat pesat, adanya perubahan muka air tanah dan kualitasnya. Ketiga, bahwa kondisi air tanah terus memburuk, sejalan dengan struktur regulasi yang tidak lengkap.

Sementara itu bahwa dasar kebijaksanaan konservasi air tanah harus memperhatikan beberapa hal berikut ini (Djaendi, 2003):

1) Sumber daya air tanah adalah karunia Tuhan Yang Maha Esa oleh sebab itu
a. pemanfaatannya harus digunakan sebesar-besarnya kemakmuran rakyat serta
b. menjaga agar sumberdaya tersebut tetap dapat dimanfaatkan secara
c. berkelanjutan (sustainable)

2) Konservasi air tanah yang nggunakan prinsip kelestarian lingkungan,

3) Konservasi sumber daya air tanah harus berpegang pada asas kemanfaatan, keseimbangan dan kelestarian yang memenuhi faktor:

a. fungsi sosial dan nilai ekonomis

b. kemanfaatan umum

c. keterpaduan

d. kelestarian

e. keadilan

f. kemandirian

g. transparansi dan akuntabilitas publik.

4) Konservasi air tanah didasarkan pada satuan wilayah cekungan air tanah secara utuh,

5) Hak atas air tanah adalah hak untuk menggunakan air tanah itu sendiri dan bukan hak untuk memiliki sumber daya tersebut,

6) Air tanah untuk air minum dan rumah tangga merupakan prioritas di atas keperluan lain.

Berdasarkan gambaran umum mengenai peraturan perundangundangan yang disebutkan di atas, maka untuk merumuskan Rancangan Peraturan Daerah Kota Bandung tentang Konservasi Air Tanah untuk agar air tanah dapat secara legal dipantau kondisinya. Peran konservasi ini kami anggap yang paling tepat untuk menghindari tumpang tindih dengan peraturan yang lebih tinggi yang belum diterbitkan, dalam hal ini Perda Provinsi. Beberapa peraturan perundangan yang diharapkan menjadi induk dari Raperda tentang konservasi air tanah ini adalah sebagai berikut:
1) UU No.
$32 / 2009$
Tentang 
Perlindungan dan Pengelolaan Lingkungan Hidup: Dalam UU ini, AMDAL mendapat porsi yang cukup banyak dibandingkan instrumen lingkungan lainnya, dari 127 pasal yang ada, 23 pasal diantaranya mengatur tentang AMDAL. Dari ke 23 pasal tersebut, ada pasal-pasal penting yang belum diatur dalam perangkat regulasi sebelumnya (UU No. 23/1997 maupun PP No. 27/1999), yaitu:

- AMDAL dan UKL/UPL merupakan salah satu instrumen pencegahan pencemaran dan/atau kerusakan lingkungan hidup;

- Penyusun dokumen AMDAL wajib memiliki sertifikat kompetensi penyusun dokumen AMDAL;

- Komisi penilai AMDAL Pusat, Propinsi, maupun kab/kota wajib memiliki lisensi AMDAL;

- Amdal dan UKL/UPL merupakan persyaratan untuk penerbitan izin lingkungan;

o Izin lingkungan diterbitkan oleh Menteri, gubernur, bupati/walikota sesuai kewenangannya.

- Sanksi terhadap orang yang melakukan usaha/kegiatan tanpa memiliki izin lingkungan;

- Sanksi terhadap orang yang menyusun dokumen AMDAL tanpa memiliki sertifikat kompetensi;

- Sanksi terhadap pejabat yang memberikan izin lingkungan yang tanpa dilengkapi dengan dokumen AMDAl atau UKL-UPL.

2) UU No. 26/2007 tentang Penataan Ruang: karena pengelolaan air tanah tidak akan lepas dari penataan ruang, bahkan jadi faktor pengendali.

3) UU No. 32/2009 tentang Pengelolaan Lingkungan Hidup: karena air secara umum merupakan bagian dari lingkungan hidup.

4) UU No. 37/2014 tentang Konservasi Tanah dan Air: karena UU ini belum memiliki peraturan teknis yang handal. Diktum tentang air tanah tapi sangat makro. Ketentuanketentuan sesuai dasar teoritis tentang pengelolaan air tanah dan konservasinya tidak dijelaskan dengan rinci.

Beberapa hal yang dikhawatirkan akan terjadi bila "regulasi antara" tidak segera dibuat adalah:

1) meningkatnya pemboran air tanah tanpa izin,

2) saat ini pihak BPLH Kota Bandung sebagai instansi pengelola air hingga tahun 2016, telah menata 850 pemboran berizin dengan hanya 50 alat Automatic Meter Recorder untuk mengukur debit pengambilan air. Sisanya dilakukan secara manual dan pelaporan mandiri dari para pemilik sumur. BPLH selalu memonitor jumlah pengambilan air secara kontinyu setiap bulan. Oleh karena kekosongan regulasi, maka dikhawatirkan pengambilan air tanah yang tidak terkendali walaupun dari sumur yang telah berizin,

3) perubahan posisi muka air tanah dan TDS pada akuifer tak tertekan (akuifer dangkal) yang terdeteksi terakhir pada tahun 2015 (Irawan et al. 2015). Lihat Gambar 4 dan Gambar 5. 

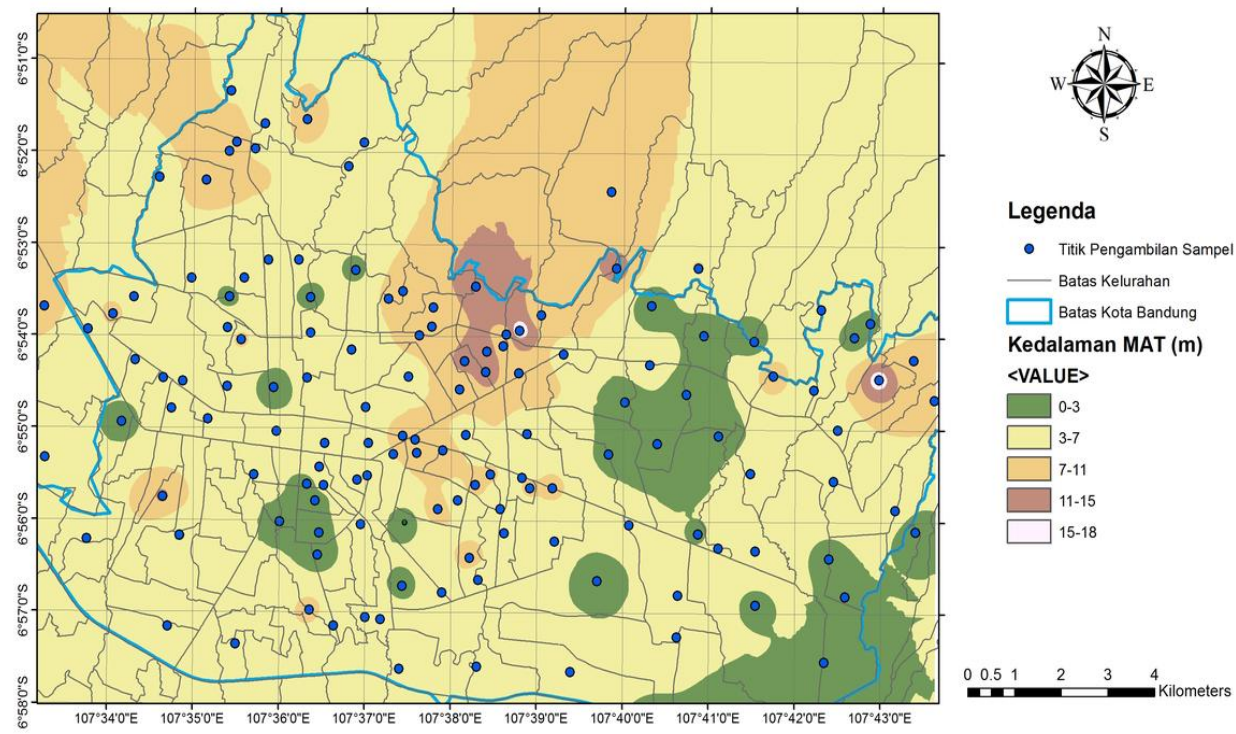

Gambar 4 Kondisi kedalaman muka air tanah tak tertekan (air tanah dangkal) di Kota Bandung (Irawan et al., 2015)
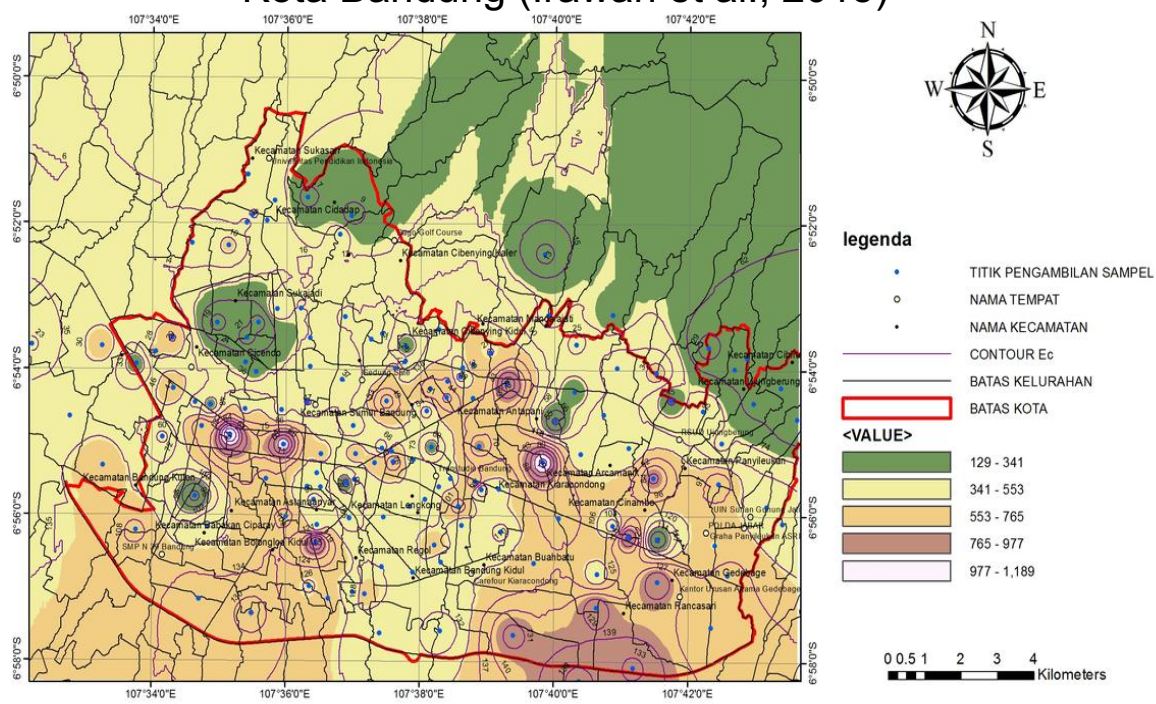

Gambar 5 Kondisi nilai eletrcial conductivity yang merncerminakan kualitas air tanah di Kota Bandung (Irawan et al., 2015)

\section{SIMPULAN DAN SARAN}

Kesimpulan ini menunjukkan pentingnya regulasi antara untuk mengisi kekosongan kebijakan. Dari uraian di atas dapat disimpulkan bahwa "regulasi antara" sangat penting untuk mengisi kekosongan. Inisiatif akan lebih penting dibanding hanya bersandar kepada prinsip hukum, bahwa kewenangan pengelolaan air saat ini berada di Pemerintah Provinsi. Regulasi antara ini dapat disusun oleh Pemerintah Kabupaten/Kota dan juga oleh Pemerintah Provinsi untuk mengatur pembagian peran pengelolaan sumber daya air.

Berdasarkan hasil dan
pembahasan, pemilihan aspek

konservasi dan pemberdayaan sebagai aspek yang dapat dikerjasamakan antara pemerintah provinsi dan pemerintah kabupaten/kota adalah pilihan yang tepat karena: aspek ini lebih berkaitan dengan aspek monitoring atau pemantauan yang tidak berhubungan dengan komponen yang paling dianggap bernilai ekonomis seperti komponen perizinan dan perpajakan. Yang mana, pemantauan akan lebih baik dilakukan oleh pemerintah kabupaten/kota karena skala pemetaan yang lebih rinci, dibanding bila dilakukan pada skala provinsi. Selain itu instrumentasi pemantauan yang dimiliki oleh organ tingkat kabupaten/kota lebih lengkap dibanding pemerintah provinsi. 
Aspek

masyarakat mengenai

pemberdayaan pentingnya konservasi air tanah juga hal yang dapat dikontribusikan oleh pemerintah kabupaten/kota. Kegiatan ini akan lebih berdampak bila dilakukan di tingkat kabupaten/kota mengingat hubungan yang lebih dekat dengan para pemangku kepentingan terutama pelaku usaha. Komponen kearifan lokal juga dapat dikenalkan dengan lebih baik dibandingkan bila dilaksanakan di tingkat provinsi yang heterogen.Selain itu aspek konservasi dipilih karena dapat menginduk kepada regulasi yang lainnya: UU No. 26/2007 tentang Penataan Ruang, UU No. 32/2009 tentang Pengelolaan Lingkungan Hidup, dan UU No. 37/2014 tentang Konservasi Tanah dan Air.

$$
\text { Saran lingkup regulasi. }
$$
Jangkauan regulasi yang kami usulkan dalam bentuk peraturan daerah (perda) ini meliputi sistem akuifer CAT BandungSoreang yang berada di wilayah administrasi Kota Bandung. Walaupun peta-peta yang akan digunakan dalam pengelolaan ini mencakup wilayah yang luas (Bandung hingga Soreang), tapi penjelasan rinci hanya akan diberikan untuk wilayah Kota Bandung.Pengaturan ini diarahkan untuk mengisi kekosongan regulasi yang saat ini terjadi. Bilamana ada aturan baru pada tingkat yang lebih tinggi, tentu saja, perda tentang konservasi air tanah ini perlu direvisi kembali. Perda ini disusun dengan prinsip bahwa: pertama, tidak ada maksud untuk mengambil alih kewenangan provinsi, semangatnya adalah berkontribusi kepada pengelolaan air tanah secara berkelanjutan. Kedua, isinya lebih dominan ke arah konservasi yang melibatkan pemantauan dan pengawasan, upaya-upaya konservasi air tanah, dilengkapi dengan sanksi dalam konteks konservasi. Ketiga, tujuan utama dari raperda ini adalah menjaga kondisi air tanah agar tidak makin rusak.

Dari beberapa prinsip tersebut, maka diusulkan lingkup substansi sebagai berikut sebagai salah satu solusi masalah ganda pengelolaan air tanah.

1. Bab Landasan Konservasi Air Tanah:
Berisi berbagai hal tentang kebijakan, strategi makro, serta kegiatan monitoring dan evaluasi air tanah. Beberapa hal tersebut harus diatur agar tidak banyak mengambil alih kewenangan provinsi.

a. Kebijakan Konservasi Air Tanah

a) Tujuan Kebijakan Konservasi

Air Tanah,

b) Prinsip Kebijakan Konservasi

Air Tanah,

c) Kewenangan Walikota.

b. Strategi Konservasi Air Tanah

a) Penetapan Strategi

Konservasi Air Tanah,

b) Penetapan Strategi

Konservasi Air Tanah dari sisi Kuantitas,

c) Penetapan Strategi Konservasi Air Tanah dari sisi Kualitas,

d) Peraturan Walikota tentang Strategi Konservasi Air Tanah.

c. Monitoring dan Evaluasi Air Tanah

a) Kegiatan Monitoring dan

Evaluasi Air Tanah,

b) Pemantauan Air Tanah,

c) Sistem Informasi Air Tanah,

2. Bab Pemberdayaan: Bagian ini merupakan salah satu yang diperlukan agar pemahaman masyarakat tentang konservasi air tanah tidak melemah.
a. Penyelenggara
Pemberdayaan,
b. Kegiatan Konservasi Air Tanah,
c. Peraturan Walikota tentang Teknis Pemberdayaan: sebagai penjelasan teknis.

3. Bab Pembiayaan kegiatan konservasi: pembiayaan perlu dilegalkan dengan menyatakan bahwa sumber dana berasal dari Anggaran Pendapatan dan Belanja Daerah (APBD) Kota Bandung.

4. Bab Sanksi: bab ini perlu didiskusikan secara intensif dengan pihak provinsi mengingat saat ini kab/kota tidak memiliki instrumen yang cukup.

5. Bab Ketentuan Peralihan dan Ketentuan Penutup. 


\section{DAFTAR PUSTAKA}

Deltares, 2012. Upper Citarum basin flood management, Vol 1: Flood management strategy, Laporan Kerja untuk Kementerian Pekerjaan Umum.

D.E. Irawan, A.D. Kuntoro, P. Natalivan, B. Bagus, $Y$. Nurhayati., $H$. Sumadi, R. Syahroni, dan N. Neni, 2015. BPLH Project on Hydrogeological Mapping of Bandung, Open Science Framework Server, DOI 10.17605/OSF.IO/RS5UD, url: osf.io/rs5ud, diakses 20 Maret 2017.

Jacob Bear, 1978. Hydraulics of Groundwater, McGraw Hill.

G. Castany, 1982. Principes et méthodes de l'hydrogéologie, Paris: Dunod.

Djaendi, 2003. Pengelolaan Air Tanah Berwawasan Lingkungan.

Bandung (ID). Direktorat Tata Lingkungan Geologi dan Kawasan Pertambangan.

Heru Hendrayana dan Doni Prakasa Eka Putra, 2008. Konservasi Air Tanah: Sebuah Pemikiran, url: https://www.researchgate.net/prof ile/Heru Hendrayana/publication/ 275964865 Konservasi AirtanahSebuah Pemikiran 2008 Heru Hendrayana Doni Prakasa EP/li nks/554c488a0cf29f836c9912c6/ Konservasi-Airtanah-SebuahPemikiran-2008-HeruHendrayana-Doni-PrakasaEP.pdf, diakses 27 Feb 2017.

I.R. Rachman, 2015. Implikasi Hukum Putusan mahkamah Konstitusi tentang Pengujian Konstitusional UU Sumber Daya Air, Jurnal Kajian Vol. 20 No. 2 Juni 2015, pp. $109-128$.

Keputusan Menteri Energi dan Sumber Daya Mineral Republik Indonesia No. 1451 K/10/MEM/2000 tentang Pedoman Teknik Penyelenggaraan Pemerintahan dibidang Air Bawah Tanah.

Keputusan Menteri Energi dan Sumber Daya Mineral Republik Indonesia No. 716K/40/MEM/2003 tentang Batas Horisontal Cekungan Air Tanah di Pulau Jawa dan Pulau
Madura.

Keputusan Menteri Energi dan Sumber Daya Mineral Republik Indonesia No. 1451 K/10/MEM/2000 tentang Pedoman

Teknis Penyelenggaraan Tugas Pemerintahan di Bidang Air Bawah Tanah.

Keputusan Menteri Energi dan Sumber Daya Mineral Republik Indonesia No. 1451K/10/MEM/2000 Tentang Pedoman Teknis Penyelenggaraan Tugas Pemerintahan di Bidang Pengelolaan Air Bawah Tanah Menteri Energi dan Sumberdaya Mineral.

Keputusan Menteri Pertambangan dan Energi Republik Indonesia No. 03.P/M/Pertamben/1983 tentang Pengelolaan Air.

Keputusan Menteri Pertambangan dan Energi Republik Indonesia No. 08P/03/M.PE/1991 tentang Perubahan Keputusan Menteri PE. No. 03.P/M/Pertamben/1983 tentang Pengelolaan Air.

Keputusan Menteri Pertambangan dan Energi Republik Indonesia No. 02P/101/M.PE/1994 tentang Pengurusan Administratif Air Bawah Tanah.

Kementerian Energi dan Sumber Daya Mineral Republik Indonesia, 2011. Peta Cekungan Air Tanah Bandung - Soreang, Skala 1: 100.000, url: http://pag.bgl.esdm.go.id, diakses 01 Feb 2017.

David N. Lerner, A.S. Issar and I. Simmers, 1997. Groundwater recharge. $A$ Guide to Understanding and Estimating Natural Recharge. International Contributions to Hydrogeology. International Association of Hydrogeologists, 8.

Mahkamah Konstitusi Republik Indonesia melalui keputusannya No. 85/PUU-XI/2013 tentang Pembatalan Undang-undang No. 7/2004 Tentang Sumber Daya Air.

S. Mandel and Z.L. Shiftan, 1981. Groundwater resources (p. 269). New York: Academic. 
Peraturan Daerah Kota Bandung No. 08 Tahun 2007 tentang Urusan Pemerintahan Daerah Kota.

Peraturan Daerah Provinsi Jawa Barat Nomor 5 Tahun 2008 tentang Pengelolaan Air Tanah.

Peraturan Pemerintah Republik Indonesia No. 22 Tahun1982 tentang Tata Pengaturan Air.

Peraturan Pemerintah Republik Indonesia No. 38 Tahun 2007 tentang Pembagian Urusan Pemerintahan antara Pemerintah Pusat, Pemerintah Daerah Provinsi, dan Pemerintah Daerah Kabupaten/Kota.

Peraturan Pemerintah Republik Indonesia No. 11 Tahun 1974 tentang Pengairan.

Peraturan Pemerintah Republik Indonesia No. 25 Tahun 2000 tentang Kewenangan Pemerintah dan Kewenangan Propinsi sebagai Daerah Otonom.

Peraturan Pemerintah Republik Indonesia No. 43 Tahun 2008 tentang Air Tanah.

Perhimpunan Ahli Airtanah Indonesia (PAAI), 2016, Quo Vadis Pengelolaan Air Tanah Indonesia, PAAI.

Puradimaja, D.J., 2006, Hidrogeologi kawasan gunung api dan karst, Pidato ilmiah Guru Besar ITB.

Shibasaki, T. ed., 1995. Environmental management of groundwater basins. Tokai University Press.

Undang-Undang Dasar Republik Indonesia 1945.

Undang-Undang No. 26/2007 tentang Penataan Ruang.

Undang-Undang No. 32/2009 tentang Pengelolaan Lingkungan Hidup.

Undang-Undang No. 37/2014 tentang Konservasi Tanah dan Air.

Undang-Undang Republik Indonesia No. 22 Tahun 1999 tentang Pemerintahan Daerah.

Undang-Undang Republik Indonesia No. 23 Tahun 2014 tentang Pemerintahan Daerah.

Undang-Undang Republik Indonesia No. 25 Tahun 1999 tentang Perimbangan Keuangan antara Pemerintah Pusat dan Daerah.

Undang-Undang Republik Indonesia No.
32 Tahun 2004 tentang

Pemerintahan Daerah.

Undang-Undang Republik Indonesia No. 32 Tahun 2009 tentang Perlindungan dan Pengelolaan Lingkungan Hidup.

Undang-Undang Republik Indonesia No. 7/2004 tentang Sumber Daya Air. 